\title{
Systemic lupus erythematosus complicated by Crohn's disease: a case report and literature review
}

Hiroyuki Yamashita, Yo Ueda, Hoshimi Kawaguchi, Akitake Suzuki, Yuko Takahashi, Hiroshi Kaneko, Toshikazu Kano and Akio Mimori

\begin{abstract}
Background: Although patients with systemic lupus erythematosus (SLE) may experience various gastrointestinal disorders, SLE and Crohn's disease (CD) rarely coexist. The diseases may have gastrointestinal (GI) manifestations, laboratory results, and radiographic findings that appear similar and consequently differentiating between Gl involvement in CD and in SLE may be difficult. We present the case of a patient with SLE and CD who developed continuous GI bleeding and diarrhea that was initially treated as SLE-related colitis to little effect.

Case presentation: A 55-year-old Japanese woman with systemic lupus erythematosus (SLE) developed continuous gastrointestinal bleeding and diarrhea since the patient was aged 30 years that was initially treated as SLE-related colitis. Although a longitudinal ulcer and aphthous ulcers in the colon were observed every examination, biopsy showed only mild inflammation and revealed neither granuloma nor crypt abscess. The patient underwent surgery for anal fistulas twice at 50 and 54 years of age and her symptoms were atypical of lupus enteritis. Colonoscopy was performed again when the patient was 55 years of age because we suspected she had some type of inflammatory bowel disease (IBD). Cobblestone-like inflammatory polyps and many longitudinal ulcers were detected between the descending colon and the cecum. Macroscopic examination strongly suggested CD. Histopathological examination revealed non-caseating granuloma and no evidence of vasculitis, consistent with CD. Introduction of infliximab dramatically relieved the patient's melena and abdominal symptoms.
\end{abstract}

Conclusion: Diagnostic criteria for CD and SLE overlap, making them difficult to diagnose correctly. It is important to consider CD for patients who have SLE with gastrointestinal manifestations. The pathology of lupus enteritis should be clarified through the accumulation of cases of SLE combined with CD.

Keywords: Systemic lupus erythematosus (SLE), Crohn's disease (CD), Longitudinal ulcer, Aphthous ulcers, Cobblestone-like inflammatory polyps, Non-caseating granuloma, Vasculitis, Infliximab

\section{Background}

Systemic lupus erythematosus (SLE) and Crohn's disease (CD) are multisystem diseases characterized by widespread tissue damage [1]. The diseases may have gastrointestinal (GI) manifestations, laboratory results, and radiographic findings that appear similar and consequently differentiating between GI involvement in $\mathrm{CD}$ and in SLE may be difficult. There are, in fact, few

\footnotetext{
* Correspondence: hiroyuki_yjp2005@yahoo.co.jp

Division of Rheumatic Diseases, National Center for Global Health and Medicine, 1-21-1 Toyama, Shinjuku, Tokyo 162-8655, Japan
}

reports suggesting an association between these diseases [2-8].

We present the case of a patient with SLE and CD who developed continuous GI bleeding and diarrhea that was initially treated as SLE-related colitis to little effect.

\section{Case presentation}

A 55-year-old woman developed rash and arthralgia when she was 19 years old. Her physician at the time diagnosed her illness as SLE because of positive antinuclear antibody (ANA) and anti-double-stranded (dsDNA) antibody results and began treatment with $30 \mathrm{mg} /$ day

\section{Biomed Central}

(c) 2012 Yamashita et al.; licensee BioMed Central Ltd. This is an Open Access article distributed under the terms of the Creative Commons Attribution License (http://creativecommons.org/licenses/by/2.0), which permits unrestricted use, distribution, and reproduction in any medium, provided the original work is properly cited. 
prednisolone (PSL), which was subsequently reduced to $10 \mathrm{mg} /$ day. Abdominal pain accompanied by diarrhea began to occur intermittently when the patient was aged 30 years. She developed fever at the age of 31 years after swimming in the sea and was admitted to our department for treatment and close examination of her chronic diarrhea. She had a high titer of dsDNA antibody, a positive result for ANA, polyarthritis, rash, and photosensitivity; therefore, we confirmed the diagnosis of SLE using the American Rheumatism Association criteria. Although colonoscopy revealed a linear ulcer, no granuloma was detected by biopsy. Due to melena and abdominal pain, she again underwent colonoscopy when she was 32 and 33 years of age. Although a longitudinal ulcer in the descending colon $(\mathrm{D} / \mathrm{C})$ and aphthous ulcers in the transverse colon $(\mathrm{T} / \mathrm{C})$ and the ascending colon (A/C) were observed during each examination, biopsy showed only mild inflammation and revealed neither granuloma nor crypt abscess. Her PSL dose was increased to $60 \mathrm{mg} /$ day during each of these hospital visits, because her symptoms were assumed to result from exacerbation of lupus enteritis. However, remission was not achieved. GI symptoms were exacerbated whenever the PSL dose was reduced to $\leq 15 \mathrm{mg} /$ day. Colonoscopy performed because of diarrhea when the patient was 39 and 49 years old revealed longitudinal ulcers in D/C and ulcerative lesions extended over a wide area from the sigmoid colon to the cecum, no significant finding was obtained by biopsy. The patient was prescribed immunosuppressants, such as azathioprine (AZA), methotrexate (MTX), or tacrolimus (TAC) in addition to PSL 10-20 mg/day and salazosulfapyridine (SASP) $3 \mathrm{~g} /$ day at an outpatient unit of the hospital. However, the patient repeatedly had melena, positive for immunological fecal occult blood, and positive for inflammatory responses. The patient underwent surgery for anal fistulas twice at 50 and 54 years of age and her symptoms were atypical of lupus enteritis. Colonoscopy was performed again when the patient was 55 years of age because we suspected she had some type of inflammatory bowel disease (IBD). Cobblestone-like inflammatory polyps and many longitudinal ulcers were detected between the descending colon and the cecum (Figure 1A). Macroscopic examination strongly suggested CD. Histopathological examination revealed non-caseating granuloma and no evidence of vasculitis (Figure 1B), consistent with CD. On November 9, 2009, the patient was hospitalized to begin infliximab treatment for $\mathrm{CD}$ at 55 years of age. Hemoglobin (Hb) was $10.9 \mathrm{~g} / \mathrm{dl}$ (normocytic), white blood cell count was $9.44 \times 10^{3} / \mathrm{ml}$ (neutrophilic leukocytes: $90.8 \%$, lymphocytes: $7.4 \%$ ), and platelets were $4 \times 10^{5} / \mu \mathrm{l}$. Serum blood urea nitrogen (BUN) was $18.7 \mathrm{mg} / \mathrm{dl}$ and creatinine (Cre) was $0.75 \mathrm{mg} / \mathrm{dl}$, with normal electrolytes, glucose, and liver function tests. Prothrombin time (PT), partial thromboplastin time (PTT), fibrinogen, and D-dimers were normal. C-reactive protein (CRP) and erythrocyte sedimentation rate were 1.19 $\mathrm{mg} / \mathrm{dl}$ and $48 \mathrm{~mm} / \mathrm{h}$, respectively. Other laboratory tests indicated the presence of ANA, anti-SS-A antibodies, normal complement levels, and a high titer of anticardiolipin (aCL)- 32 GPI $(68.9 \mathrm{U} / \mathrm{ml})$. The tests for anti-dsDNA antibodies had become negative because of the administration of steroid. Urinalysis was normal and stool cultures did not reveal any infection. Her stools were positive for occult blood.

Introduction of infliximab dramatically relieved the patient's melena and abdominal symptoms. Infliximab was administered at a dose of $5 \mathrm{mg} / \mathrm{kg}$ body weight (340 $\mathrm{mg}$ ) at weeks 0,2 , and 6 , and then every 8 weeks thereafter. Regarding inflammatory responses after 1 month of infliximab administration, the CRP level normalized from $1.19 \mathrm{mg} / \mathrm{dl}$ to $0.06 \mathrm{mg} / \mathrm{dl}$, and the erythrocyte sedimentation rate (ESR) from $48 \mathrm{~mm} / \mathrm{hr}$ to $14 \mathrm{~mm} / \mathrm{hr}$. The Harvey-Bradshaw index (HBI) score was also reduced

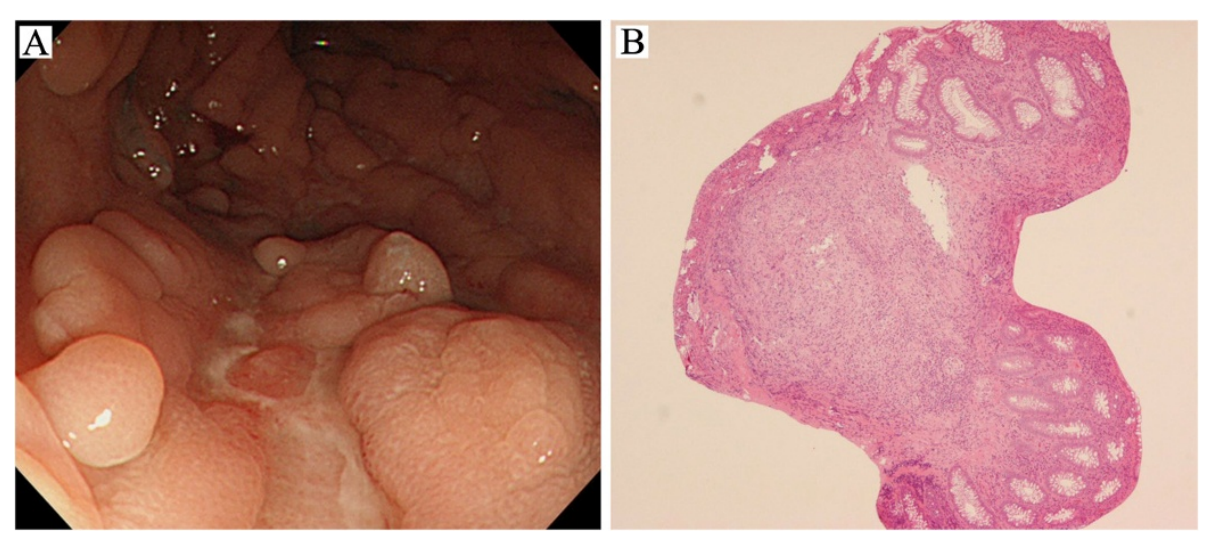

Figure 1 Findings of colonoscopy and colon biopsy specimens. (A) Macroscopic findings of colonoscopy with cobble-stone-like inflammatory polyps and many longitudinal ulcers in the descending colon. (B) Histopathological findings of specimens in A (hematoxylin and eosin, $\times 100$ ) with noncaseating granuloma and no evidence of vasculitis. 
from 5 to 0 . The patient had sustained lack of inflammatory response and negative test results for fecal occult blood. Ultimately, the PSL dose was reduced to $5 \mathrm{mg} /$ day, and both MTX and TAC were tapered to discontinuation. As of May 2012, remission is maintained with infliximab, $5 \mathrm{mg} /$ day PSL, and $3 \mathrm{~g} /$ day SASP. However, the aCL- $\beta 2$ GPI antibody titers remain high.

\section{Discussion}

Although patients with SLE may experience various GI disorders, SLE and CD rarely coexist [2-8]. Table 1 lists reports of the combination of SLE and CD. Except in Case 4, CD developed a mean of $12.0 \pm 12.2$ years after the onset of SLE symptoms. In the case reported here, the patient developed regular $\mathrm{CD}$ more than 36 years after onset of SLE. All cases were positive for antidsDNA antibodies or anti-DNA antibodies. Polyarthritis occurred as an SLE symptom in five of the seven cases.
The frequency of peripheral arthritis among CD patients is $1-22 \%$ and symptoms similar to those of collagen disease may develop [9]. Therefore, a causal relationship between SLE and CD cannot be excluded.

SLE is a multisystemic disease; therefore, patients frequently present with GI disorders that may be clinically similar to CD. However, there are some differences [4]. Compared to SLE, CD presents more frequently as diarrhea, abdominal pain, and anal lesions. All seven patients described in Table 1 experienced diarrhea, whereas five experienced abdominal pain, and two had anal lesions. CD has greater ileal involvement with a more segmented distribution than SLE, and radiographs show deep ulcers, fissures, and a cobblestone appearance or fistula formation as well as the macroscopic colonoscopy findings. Plain film radiographs of SLE-related mesenteric vasculitis usually show nonspecific indications of disease, such as segmental bowel dilatation in a thumb-

Table 1 Comparison of reported patients with SLE complicating Crohn disease

\begin{tabular}{|c|c|c|c|c|c|c|c|c|c|}
\hline $\mathrm{Pt}$ & $\begin{array}{l}\text { Age/ } \\
\text { Sex }\end{array}$ & $\begin{array}{l}\text { SLE disease } \\
\text { duration }\end{array}$ & $\begin{array}{l}\text { Immunological } \\
\text { findings }\end{array}$ & Sympotom & $\begin{array}{l}\text { ESR } \\
(\mathrm{mm} / \mathrm{hr})\end{array}$ & $\begin{array}{l}\text { Colonoscopy } \\
\text { findings }\end{array}$ & Result of biopsy & Treatment & Reference \\
\hline 1 & $28 \mathrm{M}$ & 7 years & $\begin{array}{l}\text { ANA 1280x } \\
\text { Anti-DNA 160x }\end{array}$ & $\begin{array}{l}\text { Diarrhea } \\
\text { pyoderma } \\
\text { gangrenosum }\end{array}$ & 89 & $\begin{array}{l}\text { Deep linear and } \\
\text { ulceration, } \\
\text { pseudopolyps, } \\
\text { skip lesion }\end{array}$ & $\begin{array}{l}\text { Acute and clonic } \\
\text { inflammation }\end{array}$ & $\begin{array}{l}\text { mPSL40mg/ } \\
\text { d. d iv }\end{array}$ & {$[2]$} \\
\hline 2 & $15 F$ & 3years & $\begin{array}{l}\text { ANA 1280x } \\
\text { Anti-DNA 50x }\end{array}$ & $\begin{array}{l}\text { Abdominal pain } \\
\text { Diarrhea } \\
\text { Blood stained } \\
\text { stool }\end{array}$ & 68 & $\begin{array}{l}\text { Multiple ulcers with } \\
\text { linear ulcer, skip lesion, } \\
\text { Pseudpolyps }\end{array}$ & $\begin{array}{l}\text { Infiltration of chronic } \\
\text { inflammatory cells in } \\
\text { the lamina proprial } \\
\text { mucosa with marked } \\
\text { depletion of goblet } \\
\text { cells without vasculitis }\end{array}$ & $\begin{array}{l}\text { Salazosulpha- } \\
\text { pyridine }\end{array}$ & [3] \\
\hline 3 & $55 \mathrm{~F}$ & 12years & $\begin{array}{l}\text { ANA 80× Anti- } \\
\text { dsDNA 80xpositive } \\
\text { LE cell }\end{array}$ & $\begin{array}{l}\text { Intermittent } \\
\text { hematochezia, } \\
\text { tenesmus and } \\
\text { loose bowel } \\
\text { movements }\end{array}$ & 35 & $\begin{array}{l}\text { Multiple ulcers with } \\
\text { linear ulcer, diffuse } \\
\text { aphthous ulcers }\end{array}$ & $\begin{array}{l}\text { active colitis with } \\
\text { noncaceating } \\
\text { granulomas }\end{array}$ & Prednisone & {$[4]$} \\
\hline 4 & $25 \mathrm{~F}$ & $\begin{array}{l}\text { She developed } \\
\text { SLE four years } \\
\text { after developing } \\
\text { Crohn's disease. }\end{array}$ & $\begin{array}{l}\text { ANA 160× Anti- } \\
\text { dsDNA 800IU/ml } \\
\text { pANCA positive }\end{array}$ & $\begin{array}{l}\text { Watery diarrhea } \\
\text { Lower abdominal } \\
\text { pain, Perianal } \\
\text { abscess }\end{array}$ & N/A & $\begin{array}{l}\text { Longitudinal ulcers } \\
\text { and mucosal erosion }\end{array}$ & $\begin{array}{l}\text { Focal cryptitis with } \\
\text { noncaceating } \\
\text { granuloma }\end{array}$ & $\begin{array}{l}\text { Salazosulpha- } \\
\text { pyridine 3g/d }\end{array}$ & [5] \\
\hline 5 & $37 M$ & 9years & $\begin{array}{l}\text { ANA 320× Anti- } \\
\text { dsDNA320× Anti- } \\
\text { DNA 26IU/ml } \\
\text { positive LE cell }\end{array}$ & $\begin{array}{l}\text { Diarrhea } \\
\text { hematochezia }\end{array}$ & 65 & $\begin{array}{l}\text { Longitudinal ulcers, } \\
\text { linear ulcer, cobble } \\
\text { stone appearance, } \\
\text { Pseudpolyps }\end{array}$ & $\begin{array}{l}\text { Non-specific colitis } \\
\text { without vasculitis }\end{array}$ & $\begin{array}{l}\text { Salazosulpha- } \\
\text { pyridine } 1 \mathrm{~g} / \mathrm{d} \text {, } \\
\text { Azathiop- } \\
\text { rine75mg }\end{array}$ & {$[6]$} \\
\hline 6 & $49 F$ & 5years & ANA positive & Diarrhea & N/A & $\begin{array}{l}\text { Emergent operation } \\
\text { with }\end{array}$ & $\begin{array}{l}\text { Transmural fibrosis } \\
\text { and }\end{array}$ & Mesalazine & {$[7]$} \\
\hline & & & $\begin{array}{l}\text { anti-dsDNA } \\
\text { 234IU/ml }\end{array}$ & $\begin{array}{l}\text { Abdominal pain } \\
\text { Massive bloody } \\
\text { stool }\end{array}$ & & $\begin{array}{l}\text { a right hemicolectomy } \\
\text { was performed. }\end{array}$ & $\begin{array}{l}\text { inflammation with } \\
\text { lymphocyte } \\
\text { aggregation, but no } \\
\text { evidence of vasculitis. }\end{array}$ & $\begin{array}{l}\text { Prednisone } \\
\text { 10mg b.i.d. }\end{array}$ & \\
\hline 7 & $55 F$ & 36years & $\begin{array}{l}\text { a high titer of anti- } \\
\text { dsDNA antibody } \\
\text { (at diagonosis of } \\
\text { SLE) a positive } \\
\text { result for ANA }\end{array}$ & $\begin{array}{l}\text { Diarrhea } \\
\text { Abdominal pain } \\
\text { bloody stool } \\
\text { anal fistula }\end{array}$ & 48 & $\begin{array}{l}\text { Longitudinal ulcers, } \\
\text { cobble stone } \\
\text { appearance, } \\
\text { Pseudpolyps }\end{array}$ & $\begin{array}{l}\text { active colitis with } \\
\text { noncaceating } \\
\text { granulomas } \\
\text { without vasculitis }\end{array}$ & Infliximab & $\begin{array}{l}\text { The present } \\
\text { case }\end{array}$ \\
\hline
\end{tabular}


print pattern and an air-fluid level. CT scans reveal the characteristic features of IBD (e.g., a double halo sign and comb-like appearance of the supplying vessels). Angiography of the mesenteric arteries may also provide evidence of vasculitis.

The most common pathological lesions in the GI tract of patients with SLE are chronic, nonspecific mucosal inflammation and ischemic changes due to vascular lesions. However, vasculitis was not confirmed in any of the cases presented in Table 1. Therefore, the abdominal symptoms experienced by patients with both SLE and $\mathrm{CD}$ can be attributed to $\mathrm{CD}$ alone.

Additionally, perforation rarely occurs in IBD, but is often observed in lupus enteritis, and may be helpful in differential diagnosis [10]. GI lesions associated with SLE are roughly classified into two types: (1) those associated with vasculitis and that frequently cause perforation; and (2) nonspecific ulcerative or granulomatous colitis [11]. The latter indicate that $\mathrm{CD}$ is complicating SLE. Therefore, when encountering steroid-resistant SLE-associated enteritis with the typical findings of CD, such as macroscopic findings of cobblestone-like inflammatory polyps, histopathological findings of noncaseating granuloma, and the presence of discontinuous longitudinal ulcers and aphthous ulcers in the colon, a diagnosis of $\mathrm{CD}$ should be considered in the differential, and anti-TNF- $\alpha$ therapy should be kept in mind.

Patients with IBD that is treated with sulfasalazine can, in rare cases, develop drug-induced lupus syndrome [12]. Drug-induced lupus syndrome is associated with negative ANA laboratory tests and hypocomplementemia. The patient described here was positive for ANA and anti-dsDNA antibody before the administration of SASP when she was 19 and 31 years old; therefore, drug-induced lupus syndrome was unlikely.

In early CD lesions, such as aphthous ulcers associated with noncaseating granuloma, macrophagic epithelioid cells aggregate in response to antigens from food and enteric bacteria that have invaded the intestinal mucosa. These macrophagic cells produce proinflammatory cytokines, such as interleukin-6 and tumor necrosis factor (TNF)- $\alpha$, which are considered to be important for the development of $C D$. It is for this reason that $C D$ is classified as an autoimmune disease [13]. In the case described here, administration of steroids in early-stage SLE might have delayed the onset of obvious lower GI CD lesions.

The overall prevalence of aCL antibodies among $\mathrm{CD}$ patients is approximately $22 \%$ [14]. Although the patient was strongly positive for aCL antibodies, coagulation factor levels were always within the normal range. Moreover, the patient had no history of thrombosis. Thus, concomitant antiphospholipid syndrome is unlikely.

Glucocorticosteroid is an effective treatment for CD, and can be used to treat severe cases or disease that does not respond well to mesalazine therapy. However, longterm treatment with glucocorticosteroids should be avoided. In case of steroid dependency or steroid refractory TNF-alpha blockers are an effective treatment to induce and maintain remission [15]. In the case described herein, $\mathrm{CD}$ activity was not controlled by high-dose PSL therapy or by moderate doses of steroids and SASP. However, a complete response was achieved with anti-TNF- $\alpha$ therapy. TNF- $\alpha$ inhibitors have been reported to cause drug-induced lupus, as well as rashes and arthritis [16]. Fortunately, in this case, SLE symptoms did not worsen. There are, however, occasional reports describing the efficacy of antiTNF- $\alpha$ therapy for SLE. It has also been reported that, despite levels of antibodies to ds-DNA and cardiolipin being increased, anti-TNF- $\alpha$ therapy did not exacerbate SLE itself but rather achieved a reduction in disease activity and relief of refractory arthritis, nephritis, etc. [17]. TNF- $\alpha$ exerts both deleterious tissue damaging effects mainly through its pro-inflammatory activities and beneficial activities by dampening aggressive autoimmune responses. SLE is a disease with autoimmune disturbance and inflammatory damage, so blocking TNF- $\alpha$ in this autoimmune-prone chronic inflammatory disease may lead to different outcomes, depending on timing and duration of treatment[18]. Thus, infliximab may also be effective for gastrointestinal symptoms associated with SLE.

\section{Conclusion}

In conclusion, the diagnostic criteria for CD and SLE overlap, making them difficult to diagnose correctly. It is important to consider the possibility of $\mathrm{CD}$ in patients who have SLE with GI manifestations. The status of CD as an autoimmune disease is becoming clear and the pathology of lupus enteritis should be clarified through the accumulation of cases of SLE combined with CD.

\section{Consent}

Written informed consent was obtained from the patient for publication of this Case report and any accompanying images. A copy of the written consent is available for review by the Series Editor of this journal.

\footnotetext{
Competing interests

None of the authors including Hiroyuki Yamashita, Yo Ueda, Hishimi Kawaguchi, Akitake Suzuki, Yuko Takahashi, Toshikazu Kano and Akio Mimori have any conflicts of interest associated with this case report.

Financial competing interests.

In the past five years have you received reimbursements, fees, funding, or salary from an organization that may in any way gain or lose financially from the publication of this manuscript, either now or in the future? Is such an organization financing this manuscript (including the article-processing charge)? If so, please specify. No.

Do you hold any stocks or shares in an organization that may in any way gain or lose financially from the publication of this manuscript, either now or in the future? If so, please specify. No.
} 
Do you hold or are you currently applying for any patents relating to the content of the manuscript? Have you received reimbursements, fees, funding, or salary from an organization that holds or has applied for patents relating to the content of the manuscript? If so, please specify. No, Do you have any other financial competing interests? If so, please specify. No.

Non-financial competing interests.

Are there any non-financial competing interests (political, personal, religious, ideological, academic, intellectual, commercial or any other) to declare in relation to this manuscript? If so, please specify. No.

\section{Authors' contributions}

This manuscript was written under the role assignment specified below. I $H Y$, serving as the lead and corresponding author, was primarily in charge of manuscript drafting and data analysis. YU, HK, AS, YT, TK, members of the Division of Rheumatic Diseases, National Center for Global Health and Medicine in charge of assessing the disease history of a patients. AM (Director of our institute's Division of Rheumatic Diseases) supervised drafting of the manuscript and gave final approval of the version to be published. All authors read and approved the final manuscript.

\section{Authors' information}

All of authors, H.Yamashita,MD,PhD;Y.Ueda,MD;H.Kawaguchi,MD;A.Suzuki,Md, PhD; Y.Takahashi,MD,PhD;T.Kano,MD; A. Mimori,MD,PhD, belong to the Division of Rheumatic Diseases ,National Center for Global Health and Medicine,Shinjuku-ku, Tokyo-to, Japan.

Received: 20 May 2012 Accepted: 29 November 2012

Published: 5 December 2012

\section{References}

1. Nitzan O, Elias M, Saliba WR: Systemic lupus erythematosus and inflammatory bowel disease. Eur J Intern Med 2006, 17:313-8.

2. Johnson DA, Diehl AM, Finkelman FD, Cattau EL Jr: Crohn's disease and systemic lupus erythematosus. Am J Gastroenterol 1985, 11:869-70.

3. Nagata M, Ogawa Y, Hisano S, Ueda K: Crohn's disease in systemic lupus erythematosus: a case report. Eur J Pediatr 1989, 148:525-6.

4. Buchman AL, Wilcox CM: Crohn's disease masquerading as systemic lupus erythematosus. South Med J 1995, 88:1081-3.

5. Nishida Y, Murase K, Ashida R, Sasaki O, Ozono Y, Mizuta Y, Takeshima F, Makiyama K, Kohno S: Familial Crohn's disease with systemic lupus erythematosus. Am J Gastroenterol 1998, 93:2599-601.

6. Shimizu T, Nishinarita S, Son K, Tomita Y, Yoshihiro M, Kitamura N, Horie T, Baba M, Hiranuma M: [Crohn's disease with the onset resembling systemic lupus erythematosus]. Nihon Rinsho Meneki Gakkai Kaishi 1999, 22(3):164-9. Japanese.

7. Su KY, Tsai ST, Tsay SH, Lee HT, Chen WS, Huang DF: A patient with systemic lupus erythematosus and Crohn's disease complicated with massive lower gastrointestinal bleeding, mimicking intestinal vasculitis. Lupus 2008, 17:1049-50.

8. Katsanos KH, Voulgari PV, Tsianos EV: Inflammatory bowel disease and lupus: a systematic review of the literature. J Crohns Colitis 2012, 6:735-42.

9. Scholrr-Lesnik B, Brand LJ: Selected rheumatologic and dermatologic manifestation of inflammatory bowel disease. J Am Gastoenterol 1988, 83:216-223

10. Dubnow MH, McPherson JR, Bowie EJW: Lupus erythematosus presenting as an acute abdomen. Minn Med 1966, 49:577-579.

11. Kurlander DJ, Kirsner J: The association of chronic "nonspecific" inflammatory bowel disease with lupus erythematosus. Ann Int Med 1964, 60:799-813.

12. Carr-Locke DL: Sulfasalazine-induced lupus syndrome in a patient with Crohn's disease. Am J Gastroenterol 1982, 77:614-6.

13. Braegger CP, Nicholls S, Murch SH, Stephens S, MacDonald TT: Tumour necrosis factor alpha in stool as a marker of intestinal inflammation. Lancet 1992, 339:89-91.

14. Chamouard P, Grunebaum L, Wiesel ML, Freyssinet JM, Duclos B, Cazenave $J P$, Baumann R: Prevalence and significance of anticardiolipin antibodies in Crohn's disease. Dig Dis Sci 1994, 39:1501-4.

15. Hanauer SB, Feagan BG, Lichtenstein GR, Mayer LF, Schreiber S, Colombel JF, Rachmilewitz D, Wolf DC, Olson A, Bao W, Rutgeerts P: ACCENT I Study
Group. Maintenance infliximab for Crohn's disease: the ACCENT I randomised trial. Lancet 2002, 359:1541-1549.

16. Williams EL, Gadola S, Edwards CJ: Anti-TNF-induced lupus. Rheumatology (Oxford) 2009, 48:716.

17. Aringer M, Graninger WB, Steiner G, Smolen JS: Safety and efficacy of tumor necrosis factor a blockade insystemic lupus erythematosus: an open-label study. Arthritis and Rheumatism 2004, 50:3161-3169.

18. Zhu $L J$, Yang $X$, Yu XQ: Anti-TNF-alpha therapies in systemic lupus erythematosus. J Biomed Biotechnol 2010, 2010:465898.

doi:10.1186/1471-230X-12-174

Cite this article as: Yamashita et al: Systemic lupus erythematosus complicated by Crohn's disease: a case report and literature review. BMC Gastroenterology 2012 12:174.

\section{Submit your next manuscript to BioMed Central and take full advantage of:}

- Convenient online submission

- Thorough peer review

- No space constraints or color figure charges

- Immediate publication on acceptance

- Inclusion in PubMed, CAS, Scopus and Google Scholar

- Research which is freely available for redistribution

Submit your manuscript at www.biomedcentral.com/submit
( Biomed Central 